\title{
Overcoming the Judicial Conundrum: The Road to a Diplomatic Solution
}

\author{
Francesco Francioni
}

\begin{abstract}
The role of international law and of international lawyers is at its best when it results in a 'work of reconciliation and realistic construction' (Dag Hammarskjöld, 1953). Unfortunately, it is difficult to find much of this spirit in the unfolding, regrettable and never-ending saga of Germany versus Italy. In answering the basic question of whether Germany is obliged to negotiate a settlement with Italy, this chapter argues that even if there is no hard and fast legal obligation, there is a political and moral obligation to negotiate a settlement, as indicated by paragraph 104 of the Jurisdictional Immunities Judgment of the International Court of Justice (ICJ); the same obligation is incumbent upon Italy. The current legal 'black hole' cannot be filled by further proceedings before the ICJ because immunity serves the value of the equality of states, yet equality is not a value in its own sake but is functional to the preservation of peaceful and orderly international relations and to the 'realistic construction' of conditions for the fulfilment of human rights. Negotiations in view of the creation of a joint German-Italian fund for the reparation of victims is the appropriate way to overcome the present impasse and to do justice to a whole class of victims who so far have fallen into oblivion.
\end{abstract}

\section{Introduction}

There could not have been a more appropriate time to discuss possible solutions to the legal deadlock that has followed Sentenza 238/2014 of the Italian Constitutional Court (ItCC). I appreciate that in the introductory chapter the editors have stressed that the spirit of the volume should be 'forward looking and conciliatory'. I will do my best to honour this shared ambition, convinced as I am that the very aim of

\footnotetext{
F. Francioni (四)

European University Institute, Department of Law, Florence, Italy (emeritus)

e-mail: francesco.francioni@eui.eu 
international law, and the very function of international lawyers, should be a 'work of reconciliation and realistic construction'. ${ }^{1}$

Unfortunately, I must say that it is precisely this spirit of reconciliation and realistic construction that has been lacking in the regrettable controversy between two founding members of the European Union. On the German side we have seen an insistence on a formalistic interpretation of international rules, which does justice to states and their sovereignty but hardly contributes to individual justice for victims of gross human rights violations. This has resulted in a somewhat incoherent and selective approach to reparations for victims of German World War II (WWII) crimes and in a protracted denial of justice to a whole category of victims of deportation, enslavement and massacres. On the Italian side, there has been a deplorable lack of political initiative to fill the gap resulting from the incomplete implementation of Germany's post-war reparation schemes and from the ItaloGerman agreement of 1961. This is especially regrettable since similar gaps have been filled by German compensation schemes, as already indicated in the chapter by Andreas von Arnauld. ${ }^{2}$ Faced with the passivity of the Italian government, the problem was left in the hands of judges. Italian international lawyers, or at least a significant part of them, have eagerly contributed to fuelling the hubris of ius cogens, ${ }^{3}$ convinced as they were that the problem could be solved by judges rather than by a 'work of reconciliation and realistic construction'. As is now visible, this has produced a zero-sum dispute before the International Court of Justice (ICJ) and a last-ditch defence by the ItCC declaring the unconstitutionality of the law giving effect to the ICJ judgment in the Italian legal order.

It is timely and appropriate at this point to ask whether there is, in this apparently never-ending dispute, an obligation to negotiate a settlement. The editors framed the question overall with regard to Germany, but my opinion is that the question concerns Italy as well. I will examine separately the reasons why I believe the responsibility to seek a diplomatic solution falls upon both countries.

\footnotetext{
${ }^{1}$ These are the words used by Dag Hammarskjöld in his speech at the UN General Assembly of 10 April 1953 after his election as the UN Secretary-General, reprinted in Wilder Foote (ed), Servant of Peace: A Selection of the Speeches and Statements of Dag Hammarskjöld (New York: The Bodley Head 1962), 28.

${ }^{2}$ See Andreas von Arnauld, chapter 'Deadlocked in Dualism', in this volume.

${ }^{3}$ See, for authors arguing in favour of the primacy of ius cogens norms over the principle of state immunity, Annamaria Viterbo, 'I diritti fondamentali come limite all'immunità dello Stato', Responsabilità Civile e Previdenza 69 (2004), 1030-1039; Pasquale De Sena/Francesca De Vittor, 'State Immunity and Human Rights: The Italian Supreme Court Decision on the Ferrini Case', The European Journal of International Law 16 (2005), 89-112.
} 


\section{The German Position}

There are several sources of a possible German duty to open negotiations to end the present dispute with Italy. The most immediate source is the obiter dictum pronounced by the ICJ in its Jurisdictional Immunities Judgment, ${ }^{4}$ in which, after acknowledging that recognition of Germany's immunity would unavoidably result in a form of injustice for individuals (namely the deprivation of judicial protection by their 'natural judge'), the Court went on to indicate that the claims of victims 'could be the subject of further negotiation involving the two States concerned'. 5 This judicial invitation is not perfunctory. It reflects the tension felt within the Court between two conflicting goals of international justice: on the one hand, the goal of substantive justice requiring some form of remedial action for victims of egregious violations of human rights and humanitarian standards, and, on the other hand, the goal of formal international justice arising from the core realities of international law, which require the sovereign equality of states and the rule of immunity to be respected. The ICJ was able to diffuse this tension by resorting to the rhetorical argument that immunity belongs to the category of procedural norms and that its recognition does not have any impact on rules of substantive justice, even when those rules were to belong to ius cogens. The acknowledgment of the existence of a problem of 'justice' left open by the affirmation of immunity was rendered all the more necessary after the rejection of the Italian counterclaim for reparations. What is significant in this respect is the expression of 'surprise and regret' uttered by the Court in paragraph 99 of the judgment with regard to the realization that 'Germany decided to deny compensation to a group of victims on the ground that they had been entitled to a status [prisoners of war] which, at the relevant time, Germany had refused to recognize'. ${ }^{\circ}$

These statements are not in themselves a sufficient ground to permit the construction of a perfect legal obligation for the two states to negotiate a solution to the dispute that may include some form of reparation to the victims. But their legal relevance to substantiate Germany's responsibility to begin serious negotiations in view of reparations to the surviving victims and their successors becomes more apparent when we examine the origin and overall context of this controversy. The context emerges from the attitude taken by Germany in the past two decades with regard to compensation schemes for victims of atrocities committed by the Third Reich. As already pointed out in von Arnauld's chapter, Germany has been forthcoming in accepting legal responsibility for the commission of such atrocities during the Nazi period. However, 'the patchwork of instruments set up soon after the

\footnotetext{
${ }^{4}$ ICJ, Jurisdictional Immunities of the State (Germany v Italy: Greece intervening), Judgment of 3 February 2012, ICJ Reports 2012, 99.

${ }^{5}$ Ibid, para 104. See also Paolo Palchetti, chapter 'Right of Access to (Italian) Courts über alles?', in this volume.

${ }^{6}$ Ibid, para 99. See also Jörg Luther, chapter 'A Story of 'Trials and Errors' That Might Have No Happy End', in this volume.
} 
foundation of the Federal Republic (...) was very much characterized by selectivity'. ${ }^{7}$ Certainly, such selectivity was influenced by the realities of international relations at that time, including the long Cold War period and the different degree of political pressure put on Germany by other states and groups representing victims. All this is true, but there was more: the pressure exerted upon Germany by individual claims brought by victims of Nazi crimes before national courts, especially US courts. It is well known that German reparations law was modified after the 1994 Princz case in order to cover foreign victims of Nazi crimes, ${ }^{8}$ and that in the aftermath of this case Germany agreed to set up by federal law the Foundation 'Remembrance, Responsibility and Future' (Erinnerung, Verantwortung und Zukunft) to provide a comprehensive scheme of individual compensation to former slaves, forced labourers and other victims of Nazi crimes. ${ }^{9}$ Section 11(3) of the Law provides that '[e]ligibility cannot be based on prisoner-of-war status'. Such exclusion was justified by the assumption that prisoners of war (POW) can be lawfully detained under international law. But as far as many of the Italian claimants are concerned, far from enjoying a POW-protected status under international law, they were deprived of any rights and subjected to inhuman treatment, starvation and summary execution. So, one cannot understand the logic of the POW-status argument, advanced on the German side, to exclude any form of reparation to the dwindling numbers of Italian victims. The morality of their exclusion from the compensation schemes available for similar victims of other nationalities is even more dubious when we think that the Italian deportees, and especially the 'military internees', had seen their hardship aggravated by the resentment, hatred and humiliation they received for refusing to join the Nazi-Fascist war enterprise. Considered as 'traitors', they were treated with contempt and malevolence. Now we know, however, that their silent refusal reveals their morally dignified resistance at a time of tragic uncertainty for Europe. This makes the lack of any initiative on the German side after the Ferrini judgment, and the flurry of similar cases brought before Italian courts, all the more troublesome and incomprehensible to the victims. The rigidity of Germany's denying any responsibility towards the Italian victims stands in sharp contrast to the attitude taken in the mid-1990s after the Princz case in the US. In this case, the judicial action by the victims worked as a catalyst for the establishment of a comprehensive reparation scheme; in the Italian case, it produced only a defensive reaction based on immunity, with the result of letting the dispute drag on into the present.

\footnotetext{
${ }^{7}$ See Andreas von Arnauld, chapter 'Deadlocked in Dualism', in this volume, at 319.

${ }^{8}$ Princz v Germany, 26 F 3d 1166 (DC Cir, 1 July 1994).

${ }^{9}$ See also Riccardo Pavoni, chapter 'A Plea for Legal Peace', and Filippo Fontanelli, chapter 'Sketches for a Reparation Scheme', in this volume.
} 


\section{The Italian Position}

As I have already mentioned, Italy bears its own responsibility for the continuation of this dispute and for its failure to undertake effective negotiations in view of a diplomatic solution respectful of the right of the victims. When the Ferrini judgment made clear in 2004 that the half-century pall of silence covering Nazi-Fascist war crimes and crimes against humanity was being lifted with the refusal of the Court of Cassation to grant immunity to Germany, ${ }^{10}$ it was evident that alternative diplomatic, legislative and administrative remedies were morally necessary for the respect due to the victims and politically urgent in order to defuse the time bomb that was the emerging dispute with Germany. But rather than proactively seeking a diplomatically agreed solution similar to the one reached 20 years earlier in the aftermath of the Princz case, the then Italian government found it convenient to accede to Germany's decision to bring the matter to the ICJ in the not-so-secret conviction that the real dispute was not with Germany but rather with the perceived hyperactivism of judges at a time of tense relations in Italy between the executive and the judiciary. Italy's failure in this respect is all the more regrettable because it completely sidelined the case of the victims, so belatedly claiming justice, while at the same time contradicting its own professed policy on diplomatic protection. In this respect, I wish to recall that during the preparatory work on the Draft Articles on Diplomatic Protection prepared by the International Law Commission, ${ }^{11}$ the Italian delegation at the General Assembly strongly supported a progressive development of international law on this topic and the recognition of a state's obligation to exercise the diplomatic protection of individual victims of human rights violations. ${ }^{12}$ The Italian proposal went as far as envisaging a justiciable right of victims to obtain diplomatic protection from the state. What would have been the logical implication of this legal position in the wake of the Ferrini judgment? Coherence would have required that a serious diplomatic initiative be undertaken in view of ensuring a fair recognition of the claims of the victims and at the same time eliminating the cause of the emerging dispute with Germany. Instead, the government let the matter drift further into a judicial conundrum. The parliament on its part limited itself to a cosmetic initiative by adopting Law No 296/2006, which memorialized victims of forced deportation to German camps and established procedures for the granting of medals of honour. ${ }^{13}$ Too little too late for the victims.

There is a further legal basis for Italy's responsibility to take diplomatic action in view of an international solution of this dispute. This basis is provided by a rather neglected arbitral clause contained in Article 25 of the 1961 Italo-German agreement

\footnotetext{
${ }^{10}$ Corte di Cassazione, Judgment of 11 March 2004, No 5044/2004 (Ferrini).

${ }^{11}$ ILC, Draft Articles on Diplomatic Protection, adopted by the Commission at its fifty-eighth session in 2006, UN Doc A/61/10, GAOR 61 ${ }^{\text {st }}$ Session Supp 10.

${ }^{12}$ ILC, 'Comments and Observations Received from Governments' (2006) UN Doc A/CN. 4/ 561 and Add 1-2.

${ }^{13}$ Italian Law, 27 December 2006, No 296, Art 1(1271-1276).
} 
on reparations for victims of Nazi persecution. ${ }^{14}$ That clause permits unilateral activation of an arbitral procedure to settle disputes over the interpretation and implementation of the agreement. To the best of this writer's knowledge, no initiative based on this provision has ever been undertaken by the Italian government, notwithstanding the apparent divergences between Germany and Italy over the finality of the settlement provided by this agreement and over its applicability to victims of war crimes and of crimes against humanity other than persecution. If Germany insists that the 1961 agreement should have covered all kinds of victims of Nazi crimes, why has Italy never contested such a view by seeking a third-party interpretation of the agreement on the basis of the available arbitral clause?

\section{Conclusion}

This is a sorry saga. Germany and Italy share a tragic historical role in WWII and share the responsibility for having contributed to a situation where victims of appalling crimes, including forced deportations, slave labour and civilian massacres, were not recognized as victims of war crimes and crimes against humanity eligible for compensation. This is the 'black hole' on which the ICJ expressed 'surprise and regret'.

The injustice of this situation is aggravated by the fact that victims have waited for such a long time to obtain some form of recognition and reparation, most of them are no longer alive and their descendants are also fast disappearing. This protracted injustice cannot be addressed by further proceedings before the ICJ as a response by Germany to Sentenza 238/2014. Such insistence would only exacerbate the conflict and further increase the distance between formal international justice, as administered by the ICJ, and the substantive justice sought by the individual victims. The re-affirmation of immunity by the ICJ would serve the logic of once more vindicating the realities of international relations and the related need to preserve the sovereign equality of states, but it would do little to advance the cause of individual justice, whose unavoidable place in international law was reiterated by the UN General Assembly's Resolution on Basic Principles and Guidelines on the Right to a Remedy and Reparation for Victims of Gross Violations of International Human Rights and Serious Violations of International Humanitarian Law. ${ }^{15}$ In the context of this case, and more generally from the point of view of the development of international law toward a system of global justice, the ultimate question is whether sovereign equality and immunity should be considered as values in their own sake or

\footnotetext{
${ }^{14}$ Agreement between the Federal Republic of Germany and Italy on the Settlement of Certain Property-Related, Economic and Financial Questions (Bonn, 2 June 1961), German and Italian version published in Bundesgesetzblatt II 26 June 1963 No 19, 668.

${ }^{15}$ UN General Assembly, Basic Principles and Guidelines on the Right to a Remedy and Reparation for Victims of Gross Violations of International Human Rights Law and Serious Violations of International Humanitarian Law, A/RES/60/147, 16 December 2005.
} 
rather as functional to the construction and preservation of peaceful and orderly international relations and to the fulfilment of human rights. Sentenza 238/2014 does not answer this question, being exclusively based on an argument of domestic constitutional identity and justice. But Germany and Italy could seize an opportunity that this dispute offers and attempt an answer to this question by seriously addressing the case of the victims and entering negotiations in view of reaching an agreement on the establishment of a joint fund to compensate the victims of past atrocities who have so far been left out of any available reparation scheme. Such agreement could establish criteria for the identification of 'victims', with a possible distinction between direct victims and descendants. This joint fund could also address the concern expressed by the editors of this volume about the morality and legality of 'guaranteeing the rights of "others" with the resources of a state's own citizens and taxpayers'. A joint fund would help eliminate that troubling 'other' that today seems to revisit Europe with renascent forms of nationalism. It would serve as a reminder that the European Union, and the eurozone in particular, were created not only to facilitate the market, financial transactions and transnational commerce but to reduce the historical heritage of that 'other' and of the separation of the European people.

\section{References}

De Sena, Pasquale/Francesca De Vittor, 'State Immunity and Human Rights: The Italian Supreme Court Decision on the Ferrini Case', The European Journal of International Law 16 (2005), 89-112

Foote, Wilder (ed), Servant of Peace: A Selection of the Speeches and Statements of Dag Hammarskjöld (New York: The Bodley Head 1962)

Viterbo, Annamaria, 'I diritti fondamentali come limite all'immunità dello Stato', Responsabilità Civile e Previdenza 69 (2004), 1030-1039

Open Access This chapter is licensed under the terms of the Creative Commons Attribution 4.0 International License (http://creativecommons.org/licenses/by/4.0/), which permits use, sharing, adaptation, distribution and reproduction in any medium or format, as long as you give appropriate credit to the original author(s) and the source, provide a link to the Creative Commons license and indicate if changes were made.

The images or other third party material in this chapter are included in the chapter's Creative Commons license, unless indicated otherwise in a credit line to the material. If material is not included in the chapter's Creative Commons license and your intended use is not permitted by statutory regulation or exceeds the permitted use, you will need to obtain permission directly from the copyright holder.

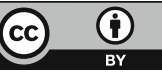

